\title{
Strengthening Counter-Radicalis Through Santri Discussion Group
}

\author{
Rindha Widyaningsih'1, Kuntarto², Muhamad Riza Chamadi ${ }^{3}$ \\ 1,2 Fakultas IImu Budaya, Universitas Jenderal Soedirman \\ ${ }^{3}$ Fakultas Biologi, Universitas Jenderal Soedirman \\ Email: 1rindha.widyaningsih@unsoed.ac.id, 2kuntarto@unsoed.ac.id, \\ 3muhamad.riza.chamadi@unsoed.ac.id \\ doi https://doi.org/10.36526/gandrung.v2i1.1187
}

\begin{abstract}
The santri group discussion aims to strengthen the character of Pancasila and the santri knowledge about issues of radicalism and terrorism in order to avoid the radicalism ideology. The activity was held at the Darul Abror Purwokerto Islamic Boarding School with 50 participants. The community service method uses a combination of community education methods and group discussions. The activity was carried out in three sessions: providing educational material, in-group discussions, and inter-group discussions. In the first session, the method provides in-depth material on radicalism and Pancasila by the community service team. The method at the second session is in-group discussion. The second session's point was to improve the participants analytical skills in responding to radicalism and Pancasila issues. The method in the third session is inter-group discussion. The santri group discussion showed that the students in Darul Abror had increased knowledge about radicalism and terrorism and developed the character of Pancasila to prevent the threat of radicalism. Students sharpen hard skills through discussion activities in practice identification and analysis of problems and problem-solving. The development of participants' soft skills is a sense of respect for other people's opinions, tolerance, and culture of deliberation.
\end{abstract}

Keyword: Community Service; Discussion; Radicalism, Pancasila

\section{Pendahuluan}

Generasi muda merupakan kelompok usia yang paling rentan terpapar dan terpengaruh paham radikalisme. Paham radikalisme menyusup dan mempengaruhi pemikiran generasi muda dengan cara yang halus dan seringkali tidak disadari (Widyaningsih, 2019). Melalui berbagai pendekatan yang seringkali menggunakan jalur keagamaan, bibit-bibit radikal tumbuh subur baik di lingkungan pendidikan bahkan di lingkungan pesantren (Purwanto \& Khoiri, 2016; Widyaningsih \& Kuntarto, 2017). Penangkapan pimpinan Pondok Pesantren Ngruki, Abu Bakar Baasyir, yang terbukti memiliki andil besar dalam perkembangan ideologi radikal di Indonesia, menjadi bukti nyata bahwa ideologi radikal dapat tumbuh dan berkembang dimanapun, bahkan di lingkungan yang memiliki nuansa keagamaan yang kuat sekalipun.

Pondok pesantren sebagai lembaga keagamaan yang melakukan kajian keagamaan secara mendalam nyatanya tidak steril dari ancaman radikalisme. Dalam banyak kasus justru ditemui bibit-bibit radikalisme menyusup dalam berbagai kegiatan keagamaan baik di lingkungan kampus maupun di 
GANDRUNG: Jurnal Pengabdian Kepada Masyarakat ISSN: 2721-6136 (Online)

lingkungan pesantren. Strategi dukungan dana dalam kegiatan kemahasiswaan merupakan cara yang paling sering dilakukan untuk menarik minat generasi muda mempelajari pemikiran-pemikiran yang dianggap revolusioner namun sesungguhnya menyusupkan paham radikalisme.

Hasil penelitian terdahulu yang telah dilakukan oleh tim menunjukkan bahwa sasaran utama ideologi radikal adalah generasi muda yang memiliki fisik kuat, cerdas, serta semangat dan komitmen yang tinggi (Widyaningsih et al., 2017a, 2017b; Widyaningsih \& Kuntarto, 2018). Melalui rekruitmen terhadap anak-anak mahasiswa yang pintar, maka mereka akan memperoleh keuntungan ganda. Mereka akan memperoleh kader militan sekaligus menjadi calon pemimpin kompeten di masa mendatang yang memiliki keyakinan dan ideologi yang sesuai dengan keinginan.

Di masa pandemi Covid 19 proses radikalisasi justru menemukan momentum emas melalui gerakan masif di dunia maya. Tingginya penetrasi terhadap internet menjadi celah yang dimanfaatkan secara cerdas untuk melakukan penyebaran dan rekruitmen secara mudah, murah dan efektif. Sekali lagi generasi muda menjadi elemen yang paling rentan terpapar dan terpengaruh ideologi-ideologi radikal(Widyaningsih \& Kuntarto, 2020). Mudahnya koneksi internet dalam genggaman tangan memungkinkan mereka mengakses konten-konten dan channel radikalisme dengan dampak yang mungkin akan dituai pada tahun-tahun mendatang. Para santri merupakan pembelajar dewasa yang memiliki rasa ingin tahu yang tinggi sehingga seringkali terjadi mereka hanya penasaran dengan ideologi radikal, mempelajarinya kemudian justru tertarik dan menjadi pendukungnya.

Sebagai negara yang menjadi target aksi terorisme internasional dan gerakan Khalifah Islamiah, Indonesia telah dan sedang menyelenggarakan berbagai strategi dan upaya penanggulangan radikalisme dan terorisme. Strategi yang digunakan meliputi hard power maupun soft power approach (Golose, 2010). Strategi ini dilakukan sebagai upaya menetralisasi pengaruh ideologi radikal, khususnya yang bersumber dari fundamentalisme agama yang intoleran, yang menjadi landasan bagi aksi terorisme.

Dalam beberapa tahun terakhir, program anti radikalisme dan deradikalisasi telah dijadikan sebagai program utama dari pemerintah dan dilaksanakan oleh berbagai instansi termasuk Badan Nasional Penanggulangan Terorisme, Polri, TNI, Badan Intelijen Negara, Kementrian Agama, dll. Dalam perkembangannya pemerintah menyadari bahwa program anti radikalisme maupun deradikalisasi akan menjadi efektif apabila mengikutsertakan para pemangku kepentingan (stakeholder) dan masyarakat.

Pencegahan radikalisme di Indonesia bahkan di seluruh dunia merupakan usaha yang memerlukan dukungan dana dan dukungan sistem yang tidak sederhana. Berbagai strategi senantiasa dikembangkan untuk melakukan anti radikalisme maupun deradikalisasi. Keterbatasan sumber daya dan 
sumber dana pemerintah tidak memungkinkan menjangkau luas geografis Indonesia dengan jumlah penduduk yang besar. Dalam hal ini partisipasi masyarakat mutlak diperlukan. Kegiatan pencegahan memerlukan dukungan besar dari masyarakat Indonesia melalui langkah yang kecil namun konsisten. Diharapkan dengan konsistensi dan prinsip gotong royong maka gerakan anti radikalisme dapat memberikan dampak yang signifikan terhadap upaya pencegahan radikalisme.

Salah satu langkah nyata yang dilakukan guna mencegah paham radikalisme tersebar di kalangan santri adalah dengan kegiatan diskusi kelompok. Melalui kegiatan diskusi kelompok, para santri diajak untuk berfikir terbuka, komprehensif dan menguatkan daya nalar analitis. Para santri diajak untuk mampu mengenali ciri-ciri pemikiran radikal, melakukan deteksi dini terhadap kemungkinan terpapar radikalisme dan pengetahuan mengenai bahaya radikalisme. Dalam kegiatan diskusi, para santri juga dibekali dengan penguatan ideologi Pancasila sehingga mampu menumbuhkan daya tangkal alami terhadap ideologi radikal. Melalui kegiatan diskusi para santri dilatih untuk mampu menyampaikan pendapatnya, bertukar pemikiran dan pengetahuan, terjadi proses dialogis namun tetap terarah karena adanya proses pendampingan. Dengan demikian maka kegiatan diskusi santri dapat menjadi sarana untuk melakukan transfer pengetahuan dan pemahaman yang bersifat analitis dan bukan semata doktriner.

\section{Metode}

Kegiatan penguatan anti radikalisme melalui kegiatan diskusi kelompok merupakan rangkaian kegiatan pengabdian kepada masyarakat yang dilaksanakan di Pondok Pesantren Darul Abror Purwokerto yang merupakan kelanjutan kegiatan yang telah dimulai pada tahun sebelumnya. Kegiatan dilaksanakan pada tanggal 17 dan 18 Agustus 2020 dengan melibatkan 50 (lima puluh) peserta yang merupakan santri dan santriwati Pondok Pesantren Darul Abror.

Kegiatan Pengabdian Kepada Masyarakat dilaksanakan dengan menggunakan kombinasi metode pendidikan masyarakat dan diskusi kelompok. Kegiatan dilaksanakan dalam tiga sesi yang terdiri dari pemberian materi edukasi, diskusi inter kelompok, dan diskusi antar kelompok.

Pada sesi pertama kegiatan dilakukan dengan menggunakan metode pendidikan masyarakat yaitu dengan memberikan pendalaman materi mengenai radikalisme dan Pancasila. Materi edukasi kepada peserta merupakan diseminasi hasil penelitian yang telah dilakukan oleh tim pengabdi dalam kurun empat tahun terakhir.

Metode pelaksanaan sesi kedua yaitu diskusi inter kelompok. Pada sesi ini peserta dibagi menjadi kelompok-kelompok kecil yang terdiri dari 5 orang peserta. Pemilihan anggota kelompok dilakukan secara acak. Pada sesi ini peserta melaksanakan kegiatan diskusi dalam kelompok dengan membahas 
GANDRUNG: Jurnal Pengabdian Kepada Masyarakat ISSN: 2721-6136 (Online)

tema sesuai dengan stimulus yang diberikan oleh tim pengabdian. Stimulus yang diberikan kepada peserta berupa studi kasus aktual yang terkait dengan tema radikalisme dan penguatan Pancasila. Titik fokus pada sesi ini adalah untuk meningkatkan kemampuan analisis peserta dalam menanggapi persoalan terkait radikalisme dan Pancasila. Pada sesi ini juga dilakukan pendampingan kepada tiap kelompok agar pelaksanaan kegiatan diskusi dapat terarah dan mendapatkan hasil diskusi yang maksimal.

Metode pada sesi ketiga yaitu dengan melakukan diskusi antar kelompok. Masing-masing kelompok memaparkan hasil diskusi inter kelompok yang telah dilaksanakan kemudian kelompok lain memberikan tanggapan dan pendapatnya. Pada sesi ini terjadi proses pertukaran ide dan pendapat antar peserta melalui proses tanya jawab dan diskusi interaktif. Titik fokus pada sesi ketiga adalah terciptanya interaksi dan bertukar pikiran serta proses menghargai pendapat orang lain. Pada sesi ini tim pengabdian berperan sebagai fasilitator kegiatan sekaligus memberikan pendampingan untuk memperdalam pengetahuan dan menjalankan proses diskusi dengan baik.

Pengukuran pemahaman peserta dilakukan dengan menilai hasil diskusi antar kelompok melalui kesesuaian antara argumentasi yang diberikan atas studi kasus yang dijadikan sebagai stimulus dengan materi yang telah disampaikan oleh tim pengabdian. Ukuran keberhasilan dari kegiatan pengabdian kepada masyarakat berbasis riset adalah para santri mengalami peningkatan pengetahuan mengenai pencegahan radikalisme dan penguatan karakter Pancasila.

\section{Hasil dan Diskusi}

Kegiatan pengabdian kepada masyarakat dilaksanakan sebanyak 3 (tiga) sesi yang dilaksanakan selama 2 (dua) hari. Peserta kegiatan adalah santri dan santriwati dari Pondok Pesantren Darul Abror Purwokerto yang berjumlah 50 (limapuluh) santri. Kegiatan didahului dengan melaksanakan koordinasi dengan pihak Pondok Pesantren Darul Abror dengan Tim Pengabdian mengenai perizinan dan teknis pelaksanaan terkait dengan pandemi Covid 19 yang memerlukan penyesuaian dan protokol kesehatan ketat.

Kondisi pandemi Covid 19 memberikan dampak besar terhadap pelaksanaan kegiatan pengabdian kepada masyarakat terkait dengan aturan pembatasan kegiatan sosial yang melibatkan banyak orang. Kegiatan pengabdian kepada masyarakat dilaksanakan dengan mentaati protokol kesehatan standar pencegahan virus Covid-19 demi mencegah penularan virus Covid-19. Protokol kesehatan yang dilakukan antara lain dengan melakukan pengecekan suhu peserta sebelum melaksanakan kegiatan dan memastikan peserta dalam kondisi prima dengan suhu tubuh tidak melebihi 
GANDRUNG: Jurnal Pengabdian Kepada Masyarakat ISSN: 2721-6136 (Online)

$37^{\circ} \mathrm{C}$, peserta diwajibkan menggunakan masker, menjaga jarak antar peserta, serta wajib mencuci tangan menggunakan sabun atau menggunakan hand sanitizer sebelum, selama dan setelah rangkaian kegiatan.

\section{Sesi Pertama}

Kegiatan pada sesi pertama berupa pemberian materi terkait dengan tema radikalisme dan terorisme serta karakter Pancasilais santri. Pemberian materi dilakukan oleh tim pengabdian yang terdiri dari tiga dosen dengan latar belakang keilmuan Pancasila, Filsafat, dan Pendidikan Agama Islam. Kegiatan pemberian materi bertujuan untuk meningkatkan pengetahuan dan pemahaman mengenai isuisu radikalisme terkini dan pentingnya karakter Pancasila sebagai upaya pencegahan radikalisme di kalangan generasi muda.

Materi pertama membahas mengenai ancaman radikalisme terhadap generasi muda serta peran dan kedudukan generasi muda dalam pembangunan bangsa. Pada materi pertama para peserta dijelaskan mengenai hasil penelitian yang telah tim pengabdian lakukan mengenai gambaran radikalisme dalam lingkup global, nasional dan daerah serta keterlibatan generasi muda dalam radikalisme dan terorisme. Dalam pemberian materi ditampilkan pula film pendek mengenai radikalisme, terorisme dan anak muda yang berjudul "Jihad Selfi" karya Huda Noor Ismail yang merupakan pemerhati dan peneliti dengan bidang kajian radikalisme dan terorisme. Melalui film pendek tersebut para peserta diajak untuk melihat fenomena dari pengalaman empiris mengenai rentannya keterlibatan anak muda dengan radikalisme dan terorisme.

Materi kedua membahas mengenai bentuk karakter santri yang mencerminkan karakter Pancasilais. Karakter santri Pancasilais pada dasarnya menekankan karakter santri yang moderat, menghargai perbedaan, tidak berfaham takfiri'. Pembentukan karakter santri merupakan dasar utama dalam proses belajar di Pondok Pesantren yang diajarkan melalui kegiatan formal maupun non formal (Suwarno, 2017). Sejumlah penelitian menunjukkan bahwa santri di Indonesia memiliki karakter kebersyukuran, keadilan, kebaikan hati, kewargaan, dan harapan (Nashori, 2011). Kegiatan pembentukan karakter memerlukan integrasi di berbagai kegiatan di Pondok Pesantren serta konsistensi sehingga mampu terinternalisasi dengan baik dalam keseharian santri Bekal karakter demikian diharapkan mampu mencetak santri yang ber-akhalkul kharimah sekaligus memiliki jiwa nasionalisme. Karakter-karakter positif inilah yang perlu dikuatkan sehingga tercipta daya tangkal terhadap ancaman radikalisme.

\footnotetext{
${ }^{1}$ Mudah mengkafirkan orang lain yang berbeda pandangan atau aliran
} 
GANDRUNG: Jurnal Pengabdian Kepada Masyarakat ISSN: 2721-6136 (Online)

Materi ketiga membahas mengenai Pancasila dan agama. Pada dasarnya Pancasila dan agama tidaklah bertentangan bahkan memiliki keselarasan. Seringkali muncul narasi-narasi yang mencoba membenturkan agama dan ideologi negara dengan memberikan pemahaman yang keliru. Awal mula ajaran-ajaran radikalisme diarahkan dengan memberikan doktrin bahwa dasar negara haruslah diganti karena tidak sesuai dengan ajaran agama, kemudian menawarkan konsep agama sebagai pengganti dasar Negara yang sah. Pola pikir demikian inilah yang coba untuk diluruskan dan didiskusikan dalam materi ketiga. Sesi pemberian materi dilakukan secara interaktif dengan lebih banyak membuka dialog dan tanya jawab. Pada akhir sesi pemberian materi, peserta diberi pertanyaan evaluasi untuk mengukur tingkat pengetahuan dan pemahaman terhadap materi. Kegiatan pada sesi pertama terlihat dalam Gambar 1 berikut:
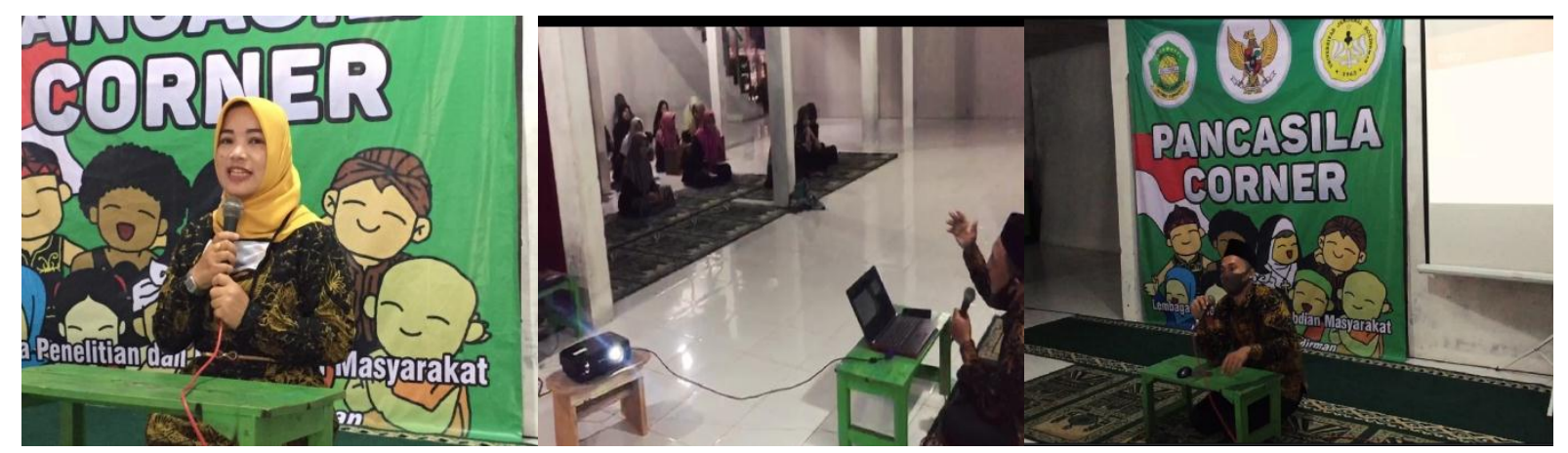

Gambar 1. Pemberian Materi Pada Sesi Pertama

\section{Sesi kedua}

Sesi kedua merupakan kegiatan diskusi internal kelompok berupa diskusi kelompok terarah (Focus Group Discussion). Dalam sesi ini peserta dibagi menjadi kelompok-kelompok kecil kemudian melakukan kegiatan diskusi internal kelompok selama 4 jam. Peserta diberi pertanyaan stimulus berupa pertanyaan terkait isu radikalisme dan terorisme serta Pancasila. Masing-masing peserta diberi kesempatan untuk menyampaikan argumentasi dan pemikirannya kemudian dirumuskan bersama sebagai hasil pemikiran kelompok. Pada saat proses diskusi peran dari tim pengabdian adalah memberikan arahan dalam berdiskusi. Pertanyaan stimulus diskusi dapat dicermati dalam tabel berikut:

Tabel 1. Pertanyaan Stimulus Diskusi

\begin{tabular}{ll}
\hline No & \multicolumn{1}{c}{ Stimulus Diskusi } \\
\hline 1 & $\begin{array}{l}\text { Bagaimanakah sikap anda apabila ada kelompok yang bertujuan merubah dasar negara } \\
\text { Pancasila? }\end{array}$ \\
\hline 2 & Menurut anda siapakah yang paling bertanggung jawab atas pencegahan radikalisme dan \\
\hline
\end{tabular}




\begin{tabular}{ll}
\hline & terorisme? Bagaimanakah peran santri? \\
\hline 3 & $\begin{array}{l}\text { Langkah apa yang mungkin anda lakukan jika melihat rekan anda terindikasi terlibat dalam } \\
\text { kelompok radikal? }\end{array}$ \\
\hline 4 & $\begin{array}{l}\text { Bagaimanakah sikap anda terhadap paham-paham asing yang bertujuan memecah belah } \\
\text { persatuan Indonesia? }\end{array}$ \\
\hline 5 & Menurut anda apakah Pancasila masih relevan? Apa alasan anda? \\
\hline 6 & Apa yang harus dibenahi agar Pancasila dipelajari secara antusias oleh generasi muda? \\
\hline 8 & Menurut anda bagaimanakah cara untuk memunculkan cinta Pancasila tanpa terpaksa? \\
\hline & $\begin{array}{l}\text { Apa yang akan anda lakukan jika kelak anda menjadi Kader Pancasila di masyarakat? } \\
\text { Langkah nyata apa yang akan anda lakukan? }\end{array}$ \\
\hline
\end{tabular}

Kegiatan diskusi internal kelompok bertujuan untuk melatih daya nalar dan analisis peserta dalam membahas mengenai topik dan isu aktual terkait dengan tema radikalisme dan Pancasila. Proses dan tahapan diskusi oleh peserta sekaligus merupakan upaya melatih hard skill dan soft skill peserta, sehingga dalam proses diskusi sendiri merupakan upaya mengasah karakter-karakter Pancasilais. Hard skill yang diperoleh oleh peserta berupa latihan identifikasi dan analisis masalah serta pemecahan permasalahan, sedangkan soft skill yang diperoleh oleh peserta adalah rasa menghargai pendapat orang lain, toleransi, dan budaya musyawarah. Kegiatan pada sesi kedua ditampilkan dalam Gambar 2 berikut:
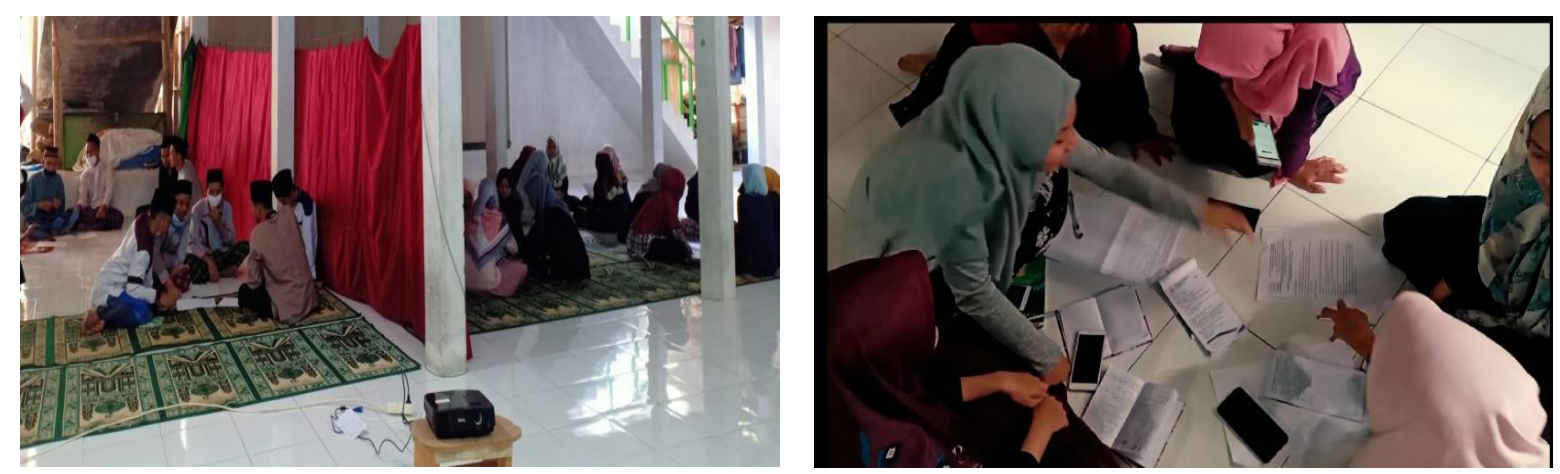

Gambar 2. Proses Diskusi Intern Kelompok

\section{Sesi Ketiga}

Kegiatan pada sesi ketiga merupakan diskusi antar kelompok. Masing-masing kelompok diberi kesempatan untuk melakukan presentasi hasil diskusi intern kelompok dalam waktu 20 menit. Dalam kegiatan diskusi antar kelompok peserta menyampaikan hasil pemikiran dan argumentasi melalui pemaparan yang kemudian ditanggapi oleh peserta lain. Peserta dipersilahkan mengajukan pertanyaan atau melakukan debat atas pemaparan kelompok yang melakukan presentasi sehingga tercipta komunikasi dua arah yang dialogis.

Dalam sesi ketiga Tim Pengabdian Kepada Masyarakat bertindak sebagai moderator dan 
GANDRUNG: Jurnal Pengabdian Kepada Masyarakat ISSN: 2721-6136 (Online)

memberikan arahan jalannya presentasi. Kegiatan diskusi antar kelompok diikuti oleh santri dengan antusias yang nampak dalam interaksi, debat dan pertukaran pemikiran antar peserta. Sesi diskusi dan pemaparan hasil pada dasarnya merupakan sarana belajar dan melatih diri untuk menyampaikan argumentasi secara ilmiah, berdasar dan melalui proses yang sehat. Kegiatan diskusi antar kelompok ditampilkan dalam Gambar 3 berikut:
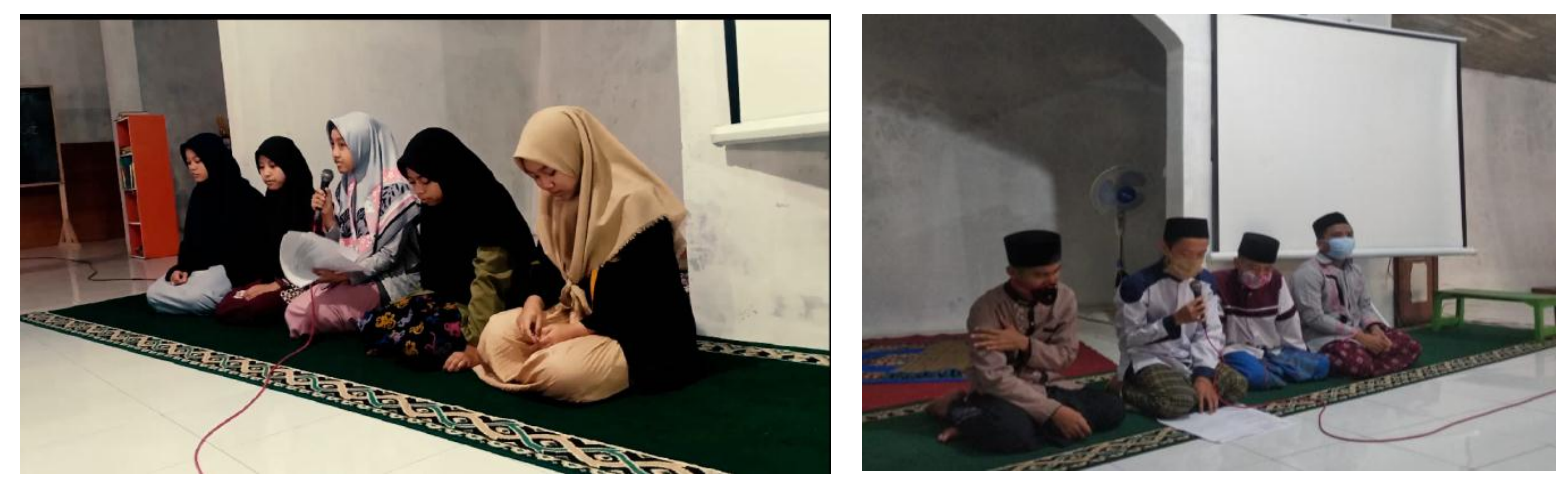

Gambar 3. Proses Diskusi Antar Kelompok

Evaluasi pemahaman peserta sekaligus dilakukan pada akhir sesi ketiga dengan menilai kesesuaian antara argumentasi hasil diskusi antar kelompok dengan materi yang telah disampaikan sebelumnya. Ketika santri memiliki pemahaman yang kurang memadai maka Tim Pengabdian Kepada Masyarakat kembali memberikan penjelasan untuk memantapkan pengetahuan dan pemahaman peserta terkait karakter Pancasila maupun tentang radikalisme.

\section{Kesimpulan}

Kegiatan pengabdian kepada masyarakat yang dilaksanakan di Pondok Pesantren Darul Abror Purwokerto merupakan upaya untuk memberikan pemahaman dan penguatan generasi muda, terutama dari kalangan santri, agar tidak mudah terpengaruh ideologi radikalisme. Kegiatan pengabdian kepada masyarakat dilaksanakan sebagai wujud tanggungjawab akademisi untuk berperan aktif dan berkontribusi dalam menyelesaikan persoalan bangsa. Melalui diseminasi dan implementasi hasil penelitian yang telah dilakukan oleh tim pengabdian melalui kegiatan diskusi, peserta mampu mengasah hard skill maupun soft skill yang kelak berguna dalam kehidupan bermasyarakat. Kegiatan pengabdian kepada masyarakat ini juga diharapkan mampu melahirkan tradisi diskusi dan musyawarah sehingga karakter-karakter positif dapat terinternalisasi dalam diri santri.

Volume 2, Number 1, Februari 2021 | 113 
GANDRUNG: Jurnal Pengabdian Kepada Masyarakat ISSN: 2721-6136 (Online)

\section{Ucapan Terima Kasih}

Penulis mengucapkan terima kasih kepada LPPM Universitas Jenderal Soedirman atas pembiayaan kegiatan Pengabdian Kepada Masyarakat melalui hibah Pengabdian Kepada Masyarakat Berbasis Riset tahun 2020.

\section{Daftar Referensi}

Golose, P. R. (2010). Deradikalisasi Terorisme Humanis, Soul Approach dan Menyentuh Akar Rumput. YPKIK.

Nashori, F. (2011). Kekuatan Karakter Santri. Millah, 11(1), 203-219. https://doi.org/10.20885/millah.vol11.iss1.art10

Purwanto, Y., \& Khoiri, S. (2016). Studi Agama \& Etika Islam dan Keberagamaan Mahasiswa "Z" Generation: Kajian di Lingkungan Kampus ITB Bandung." Walisongo: Jurnal Penelitian Sosial Keagamaan, 24(2), 423. https://doi.org/10.21580/ws.24.2.1182

Suwarno. (2017). Pondok Pesantren dan Pembentukan Karakter Santri ( Studi tentang Pengembangan Potensi-Potensi Kepribadian Peserta Didik Pondok Pesantren Terpadu Almultazam Kabupaten Kuningan ). Jurnal IImiah Kajian Islam, 2(1), 79-91.

Widyaningsih, R. (2019). Deteksi Dini Radikalisme. Unsoed Press.

Widyaningsih, R., \& Kuntarto. (2018). Family Suicide Bombing: A Psychological Analysis Of Contemporary Terrorism. Walisongo, 26(2), 295-320. https://doi.org/DOI: http://dx.doi.org/10.21580/ws.26.2.3111

Widyaningsih, R., \& Kuntarto. (2017). Kerentanan Radikalisme Agama Di Kalangan Anak Muda. Pengembangan Sumber Daya Perdesaan Dan Kearifan Lokal Berkelanjutan VII, 6, 1553-1562.

Widyaningsih, R., \& Kuntarto, K. (2020). Determinan Keterlibatan Perempuan dalam Gerakan Radikalisme. MATAN: Journal of Islam and Muslim Society, 2(1), 40-56. https://doi.org/https://doi.org/10.20884/1.matan.2020.2.1.2251

Widyaningsih, R., Sumiyem, \& Kuntarto. (2017a). Kerentanan Radikalisme agama dikalangan anak muda. Prosiding Seminar Nasional Dan Call for Papers "Pengembangan Sumber Daya Perdesaan Dan Kearifan Lokal Berkelanjutan, 6, 1553-1562. https://doi.org/10.1088/1755$1315 / 255 / 1 / 012049$

Widyaningsih, R., Sumiyem, S., \& Kuntarto, K. (2017b). The Potential of Religious Radicalism Movement in Banyumas. Walisongo: Jurnal Penelitian Sosial Keagamaan, 25(1), 203. https://doi.org/10.21580/ws.25.1.1807 